\title{
PENGARUH SOFTWARE MODELLUS SEBAGAI MEDIA SIMULASI VIRTUAL TERHADAP KEMAMPUAN BERPIKIR KREATIF MAHASISWA PADA MATA KULIAH FISIKA
}

\author{
Eka Maryam \\ eka_maryam@univbinainsan.ac.id \\ Universitas Bina Insan, Kota Lubuklinggau, Sumatera Selatan, Indonesia
}

\begin{abstract}
Received: 30 November $2021 \quad$ Revised: 1 Desember $2021 \quad$ Accepted: 17 Desember 2021
\end{abstract}
\begin{abstract}
The purpose of this study was to determine the effect of using Modellus software as a virtual simulation medium on students' creative thinking skills in physics courses. The form of this research design uses a quasi-experimental. The population in this study were all first semester students of the computer systems engineering study program at the Human Development University. While the sample in this study is the Reg Al class as the control class and the Reg A4 class as the experimental class, which were taken using a random technique. The instrument used in data collection in this study was a description test. The description test is used to determine or measure creative thinking skills. The results of the study showed that the use of Modellus software had an effect on increasing students' creative thinking skills which could be seen from the significant increase in learning outcomes, which was 56\% of the average initial score (Pretest). Meanwhile, when viewed from the results of the $N$-Gain test, the average increase in test results in the high category is 0.63 from the average post-test score for the experimental class.
\end{abstract}

\begin{abstract}
Abstrak: Tujuan dari penelitian ini adalah untuk mengetahui pengaruh penggunaan software modellus sebagai media simulasi virtual terhadap kemampuan berpikir kreatif mahasiswa pada mata kuliah fisika. Bentuk desain penelitian ini menggunakan quasi eksperiment. Populasi dalam peneltian ini yaitu selutuh mahasiswa semester satu prodi rekayasa sistem komputer universitas bina insan. Sedangkan sampel dalam penelitian yaitu kelas Reg A1 sebagai kelas kontrol dan Reg A4 sebagai kelas eksperimen, yang diambil menggunakan tenik random. Instrumen yang digunakan dalam pengumpulan data dalam penelitian ini yaitu tes uraian. Tes uraian digunakan untuk mengetahui atau mengukur kemampuan berpikir kreatif. Hasil dari penelitian didapatkan penggunaan software modellus berpengaruh terhadap peningkatan kemampuan berpikir kreatif mahasiswa yang dapat dilihat dari peningkatan hasil belajar yang signifikan yaitu sebesar $56 \%$ dari rata-rata nilai prolehan awal (Pretest). Sedangkan jika dilihat dari hasil uji $N$-Gain didapatkan kenaikan rat-rata hasil ujian pada katagori tinggi yaitu sebesar 0,63 dari hasil rata-rata nilai ujian postest kelas eksperimen.
\end{abstract}

Kata kunci: Pengaruh, software modellus, simulasi, berfikir kreatif

\section{PENDAHULUAN}

Pesatnya perkembangan ilmu pengetahuan dan teknologi (IPTEK) sangat berpengaruh diberbagai bidang kehidupan manusia termasuk dalam dunia pendidikan. Pendidikan merupakan kebutuhan yang sangat penting bagi setiap orang untuk dapat menumbuhkan dan mengembangkan kemampuan atau potensi yang dimiliki (Sari et al., 2021). Perkembangan IPTEK dapat membantu dalam meningkatkan mutu pendidikan yaitu denagan memvasilitasi penggunaan teknologi dalam pembelajaran. Di era globalisasi, pendidikan 
dengan ilmu pengetahuan dan teknologi (IPTEK) sangat erat kaitannya, serta mempengaruhi perkembangan inovasi bahan ajar (Malina, I., Yuliani, H., \& Syar, N. I, 2021). Pembuatan simulasi dalam pembelajaran tidak terlepas dari bantuan program komputer untuk mewujudkannya (Rezeki \& Ishafit, 2017). Simulasi komputer adalah suatu bentuk program komputer yang bertujuan untuk memvisualisasikan atau mencontoh suatu sistem yang nyata dalam bentuk interactive simulation (Gong, 2021). Sedangakan media simulasi virtual adalah alat bantu untuk mencapai tujuan pembelajaran berupa pemodelan dengan bantuan komputer yang di tampilkan secara daring (dalam jaringan). Media simulasi sangat dibutuhkan mahasaiswa untuk mendapatkan pengganti kegiatan praktikum atau eksperimen yang sulit untuk dilaksanakan pada masa pandemi covid-19 (Radianti et al., 2020). Kesulitan yang dihadapi mahasiswa adalah kesulitan dalam memahami konsep grafik dan konsep fisis. Dari hasil wawncara yang dilakukan peneliti pada 50 mahasiswa semester Dua Universitas Bina Insan 25 mahasiswa memberikan jawaban fisika itu sulit, 13 mahasiswa mengatakan cukip sulit dan sisanya 12 mahasiswa memberikan jawaban bervariasi yaitu ada yang mudah, sedang dan sulit. Sedangkan dilihat dari hasil nilai ujian tengah semester hanya $34 \%$ mahasiswa yang mendapatkan nilai baik atau nilai tuntas. Berdasarkan rendahnya hasil ujian tersebut, didiagnosa kemampuan berpikir kreatif mahasiswa yang kurang dalam belajar adalah penyebab utama timbulnya masalah dari kesulitan mahasiswa. Menurut (Nurdiana et al., 2020) berpikir kreatif adalah keterampilan menemukan hal-hal baru yang belum ada sebelumnya, mengembangkan solusi baru untuk setiap masalah, dan melibatkan kemampuan untuk menghasilkan ide-ide baru, variatif, dan unik. Sedang menurut (Leen et al., 2014) kemampuan berfikir kreatif dalam memecahkan masalah ini terdiri dari fluency (kemampuan untuk menghasilkan banyak ide), Flexibility (kemampuan untuk menghasilkan berbagai jenis atau kategori dari ide ide), Originality (kemampuan untuk menghasilkan ide-ide orisinal), dan Elaboration (kemampuan untuk menambahkan detail pada ide).

Untuk meningkatkan kemampuan berpikir kreatif mahasiswa terutama pada mata kuliah fisika dosen dapat memanfaatkan media simulasi dalam pengajaran fisika. Penggunaan media simulasi merupakan salah satu alternatif dalam mengatasi masalah pembelajaran fisika yang terkesan sulit khususnya materi gelombang. Media adalah alat penghubung atau perantara yang digunakan untuk mengirim pesan (Fahrudin, 2018). Sehingga media pembelajaran adalah alat bantu pembelajaran yang digunakan untuk membantu mencapai tujuan dari kegiatan belajar mengajar atau dalam proses pembelajaran yang berlangsung (Melianti et al., 
2020). Tujuan dari adanya media adalah untuk mempermudah dalam peyampaian materi ajar dari dosen kepada mahasiswa, sehingga tercapai tujuan dari pembelajara (Anisa et al., 2020).

Seorang dosen dalam dunia akademik dituntut harus mempunyai kemampuan high level skills salah satunya adalah kemampuan berinovasi. Kemampuan berinovasi dalam melakukan pembelajaran merupakan suatu kemampuan yang harus dimiliki oleh seorang dosen, salah satu inovasi dalam melakukan kegiatan pembelajaran adalah penggunaan software modellus sebagai media simulasi. Software modellus adalah seuatu perangkat lunak yang dibuat khusus untuk memudahkan dalam pengajaran fisika, didalam mengunakannya software modellus memungkinkan untuk membuat sebuah aplikasi baru tanpa keterampilan pemrograman khusus (R. G. M. Neves et al., 2013). software medellus dapat digunakan untuk membuat suatu simulasi interaktif, sekaligus menjabarkan persamaan matematis dan menampilkan grafik dalam waktu yang bersamaan (R. G. Neves et al., 2010). Modellus dibuat dengan bentuk interaktif yang dapat menggambarkan konsep-konsep ilmiah didalam mata kuliah fisika, selain itu kelebihan dari software modellus adalah materi fisika dapat disajikan dengan grafik, tabel data, animasi, simulasi dan persamaan matematis serta diilengkapi dengan lembar kerja (Rezeki \& Ishafit, 2017). Contoh Penggunaan Software modellus disajikan pada gambar berikut.

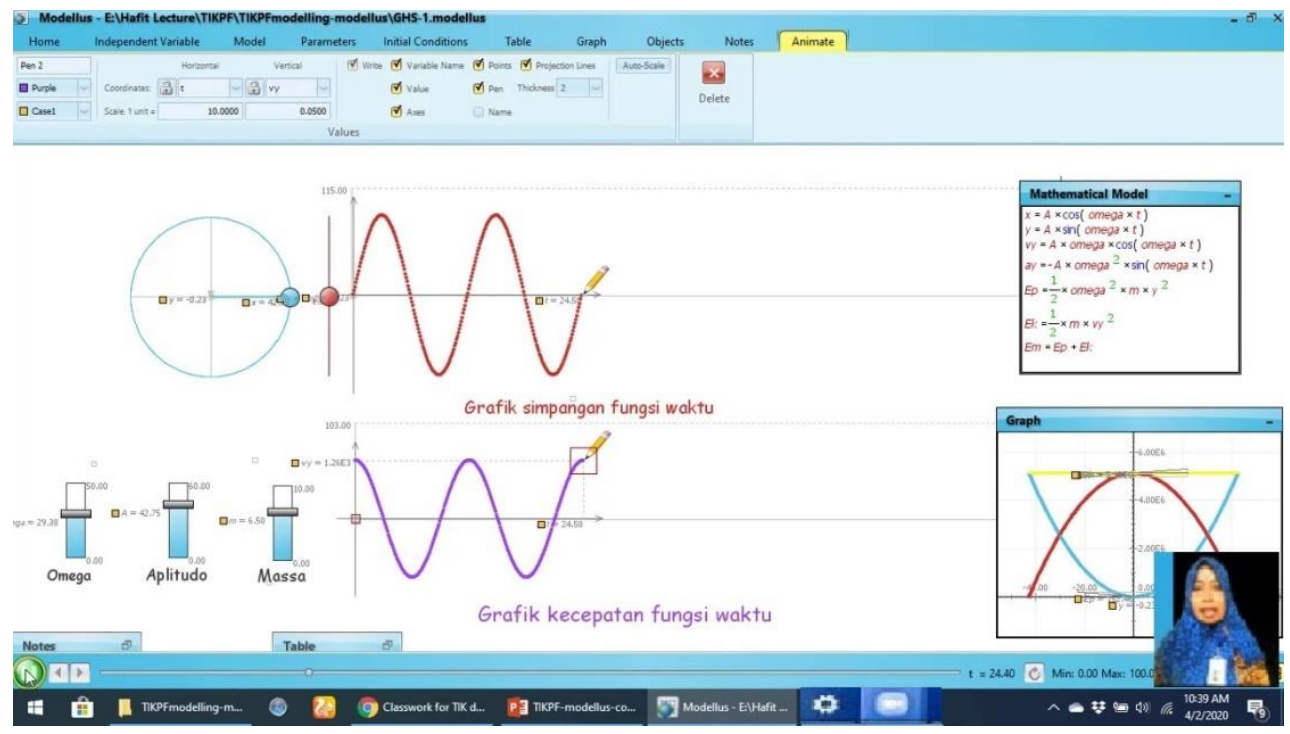

Gambar 1. Salah satu contoh simulasi virtual menggunakan software model 


$$
\begin{aligned}
& \sum F_{x}=-k x-b v=m a_{x} \\
& -k x-b \frac{d x}{d t}=m \frac{d^{2} x}{d t^{2}} \\
& x=A e^{-\frac{b}{2 m} t} \cos (\omega t+\phi)
\end{aligned}
$$

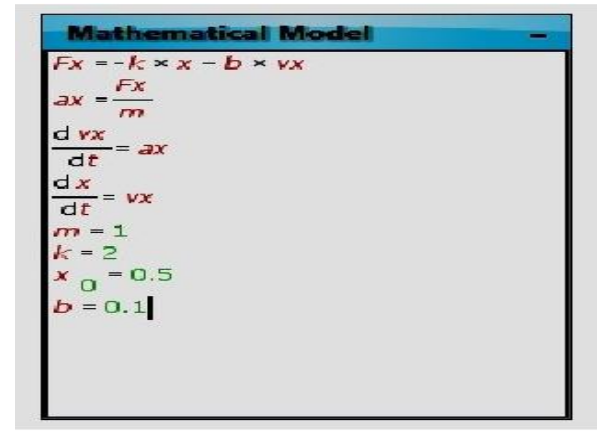

Gambar 2. Teori gelombang teredam

$$
\begin{aligned}
& \text { Gambar 3. Contoh penulisan } \\
& \text { perersamaan matematis gelombang } \\
& \text { teredam pada software modellus }
\end{aligned}
$$

Dalam memahami materi Fisika dibutuhkan penguasaan konsep matematis dan pemahaman konsep-konsep yang mendasar, karena penguasaan matematis serta pemahaman konsep yang mendasar dapat membantu menumbuhkan kemampuan berpikir kreatif (Lusiyana et al., 2017). Dari kemampuan berpikir kreatif diharapkan mahasiswa mampu menggunakannya untuk membangkitkan ide baru dan menarik, menganalisis sebuah permasalahan, mencari sebuah solusi dan melakukan evaluasi sehingga menghasilkan mahasiswa yang dapat menemukan solusi dari permasalahan yang dihadapi serta dapat dipertanggung-jawabkan secara teori dan ilmiah.

\section{METODE PENELITIAN}

Penelitian ini menggunakan metode experiment untuk mengetahui pengaruh penggunaan software modellus sebagai media simulasi virtual terhadap kemampuan berpikir kreatif mahasiswa pada mata kuliah fisika. Sedangkan desain pennelitian yang digunakan adalah desain the non equivalent control group dengan tipe penelitian quasi eksperiment. Quasi experiment dipilih karena dalam penelitian ini masih banyak faktor yang tidak bisa dikontrol oleh peneliti. Desain penelitian dapat dilihat pada tabel berikut:

Tabel 1. Desain Penlitian

\begin{tabular}{cccc}
\hline Kelas & Pretest & Perlakuan & Postest \\
\hline Kelas eksperimen & X1 & $\begin{array}{c}\text { Software modellus sebagai } \\
\text { media simulasi virtual }\end{array}$ & X2 \\
Kelas kontrol & X3 & Tanpa media & X4 \\
\hline
\end{tabular}


Sumber (Creswell, 2011)

Keterangan :

$\mathrm{X} 1=$ Pretest pada kelas eksperimen

$\mathrm{X} 2$ = Postest pada kelas eksperimen

$\mathrm{X} 3=$ Pretest pada kelas kontrol

$\mathrm{X} 4$ = Postest pada kelas kontrol

Pengumpulan data penelitian dilakukan dengan instrumen tes. Tes yang digunakan untuk mengukur kemampuan berfikir kreatif mahasiswa berupa tes uraian dengan jumlah soal sebanyak 20 soal. Sebelum digunakan dalam penelitian kedua instrumen sudah dilakukan uji validitas, reliabilitas, uji daya beda soal dan uji kesukaran soal. Adapun indikator untuk mengukur kemampuan berfikir kreatif yaitu 1) lancar atau fluency, 2) kemampuan berpikir fleksibel (3) orisinal, dan 4) kemampuan memperinci atau elaboration. Adapun indikator-indikator pada aspek penilaian kemampuan kreatif mahasiswa dalam tes uraian dapat dilihat pada tabel 3.

Tabel 3. Indikator-indikator pada aspek penilaian kemampuan kreatif mahasiswa

\begin{tabular}{|c|c|c|c|}
\hline Aspek-aspek & Indikator & Kreteria Penilaian & Skor \\
\hline \multirow[t]{5}{*}{$\begin{array}{l}\text { lancar atau } \\
\text { fluency }\end{array}$} & \multirow{5}{*}{$\begin{array}{l}\text { Lancar dalam menemukan } \\
\text { solusi pada tiap maslah } \\
\text { dengan lebih dari satau } \\
\text { jawaban }\end{array}$} & Tidak mampu menemukan solusi & 0 \\
\hline & & Memberikan solusi, namun salah & 1 \\
\hline & & $\begin{array}{l}\text { Memberikan solusi, namun belum } \\
\text { selesai }\end{array}$ & 2 \\
\hline & & $\begin{array}{l}\text { Mampu memberikan satu cara } \\
\text { penyelesaian, lengkap dan benar }\end{array}$ & 3 \\
\hline & & $\begin{array}{l}\text { Mampu memberikan lebih dari satu } \\
\text { cara penyelesaian, dan benar }\end{array}$ & 4 \\
\hline \multirow{5}{*}{$\begin{array}{l}\text { Berfikir asli } \\
\text { atau orisinal }\end{array}$} & \multirow{5}{*}{$\begin{array}{l}\text { Mampu menjwab dengan } \\
\text { benar dan memberi } \\
\text { jawaban dengan cara } \\
\text { laian yang berbeda dari } \\
\text { jawaban yang sudah biasa }\end{array}$} & Tidak mampu menemukan solusi & 0 \\
\hline & & Mampu menjawab, namun hasil salah & 1 \\
\hline & & $\begin{array}{l}\text { Mampu menjawab, namun jawabanya } \\
\text { terlalu sederhana tetapi mendekati } \\
\text { benar }\end{array}$ & 2 \\
\hline & & $\begin{array}{l}\text { Mampu menjawab dengan benar, } \\
\text { namun cara penyelesiannya masih biasa }\end{array}$ & 3 \\
\hline & & $\begin{array}{l}\text { Mampu menjawab dengan cara yang } \\
\text { berbeda, orisinal dan hasilnya benar. }\end{array}$ & 4 \\
\hline Flexibility & Mampu mengembangkan & Tidak memberikan penyelesaian & 0 \\
\hline
\end{tabular}




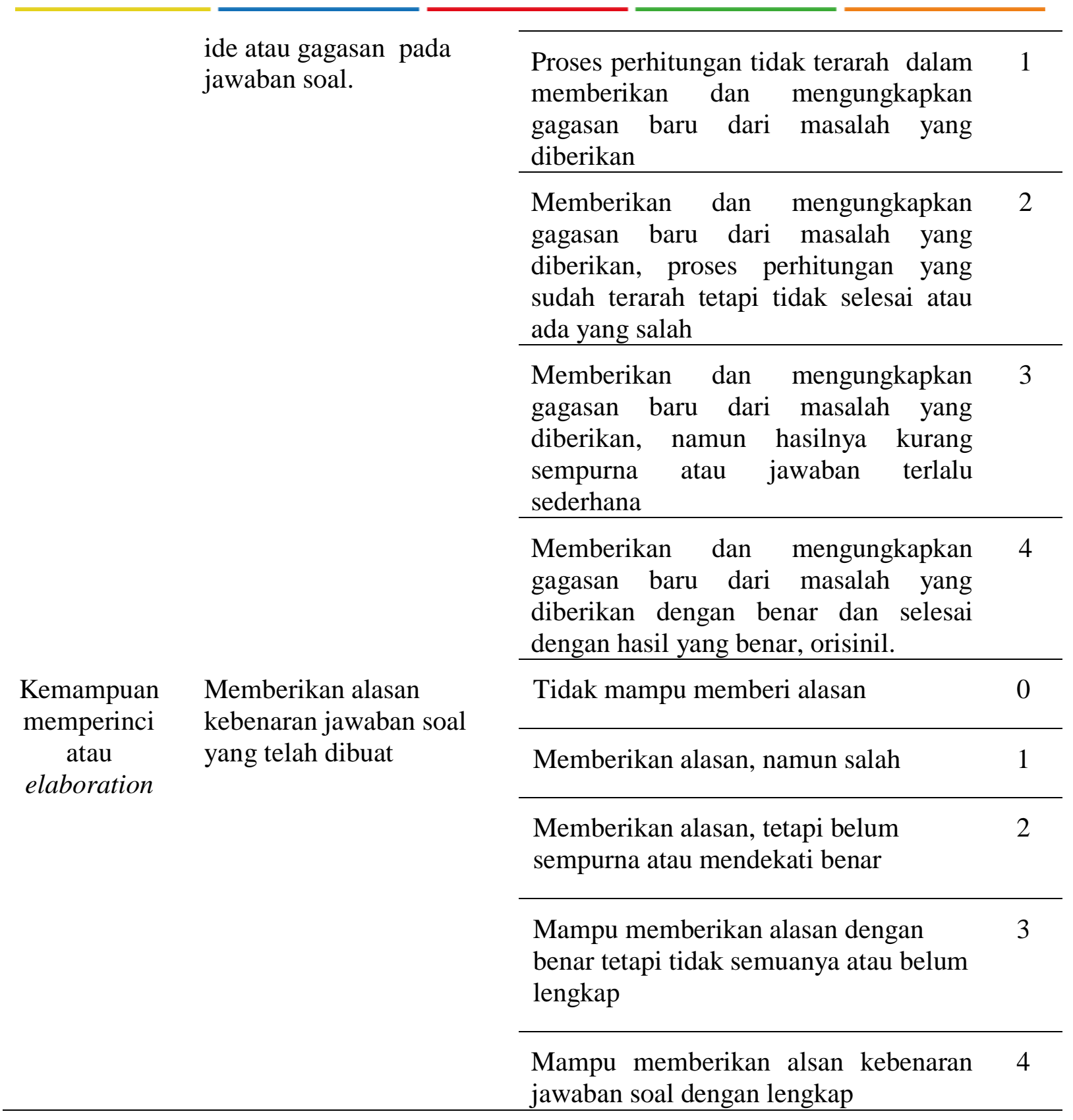

Analisis data pada penelitian ini menggunakan uji $\mathrm{t}$ dan uji $\mathrm{N}$-gain. Uji $\mathrm{t}$ yang digunakan adalah uji t independen, uji ini digunakan untuk membandingkan rata-rata dua kelompok yang tidak berhubungan satu sama lain (dua sampel bebas) dengan tujuan untuk mengetahui apakah secara signifikan kedua sampel mempunyai rata-rata yang sama atau tidak. Uji $\mathrm{t}$ ini dilakukan dengan mengguakan software SPSS. Sebelum dilakukan uji t dilakukan uji prasarat terlebih dahulu yaitu uji normalitas dan uji homogenitas. Dalam analisis data juga dilakukan uji statistik untuk mencari nilai rata-rata (mean), standar deviasi, nilai terendah dan nilai tertinggi yang digunakan untuk menentukan kelompok mahasiswa dengan kemampuan 
berfikir kreatif tinggi, sedang dan rendah. Adapun klasifikasi pembagian kategori tinggi, sedang dan rendah ditunjukkan pada tabel 4 berikut.

Tabel 4. Klasifikasi pembagian kategori tinggi sedang dan rendah

\begin{tabular}{lll}
\hline Klasifikasi & Nilai & Ketentuan klasifikasi nilai \\
\hline Kategori tinggi & $X_{\text {tinggi }}$ & \\
Kategori sedang & & $X \geq \bar{X}+S D$ \\
Kategori Rendah & $X_{\text {sedang }}$ & \\
& $X_{\text {rendah }}$ & \\
& & $X \leq \bar{X}-S D$ \\
\hline
\end{tabular}

Sumber (Arikunto, 2016)

Keterangan

$\mathrm{SD}=$ setandar deviasi

$\bar{X}=$ rata- rata nilai

$\mathrm{X}=$ nilai mahasiswa

Pada tahap Analisis data penelitian dilakukan uji t untuk menguji hipotesis penelitian (Angellena et al., 2020). Adapun persamaan uji t idependen yaitu :

$$
t=\frac{\mathrm{Mx}-\mathrm{My}}{\sqrt{\left(\frac{\Sigma X^{2}+S Y^{2}}{N_{X}+N_{Y}-2}\right)\left(\frac{1}{N_{X}}+\frac{1}{N_{Y}}\right)}}
$$

Keterangan:

Mx: Nilai rata-rata hasil perkelompok eksperimen

My: Nilai rata-rata hasil perkelompok kontrol

$\mathrm{X} \quad$ : Varian setiap nilai $X_{2}$ dan $X_{1}$

Y : Varian setiap nilai $Y_{2}$ dan $Y_{1}$

$\mathrm{Nx} \quad$ : Jumlah subjek kelompok treatment

Ny : jumlah subjek kelompok kontrol

(Arikunto, 2013:354)

Sedangkan rumusan uji hipotesis hipotesis penelitian yaitu:

$\mathrm{Ha}$ : Terdapat pengaruh penggunaan software modellus sebagai media simulasi virtual terhadap kemampuan berpikir kreatif mahasiswa pada mata kuliah fisika dan 
H0 : Tidak terdapat pengaruh penggunaan software modellus sebagai media simulasi virtuals terhadap kemampuan berpikir kreatif mahasiswa pada mata kuliah fisika.

Dimana $\mathrm{H}_{0}$ diterima jika nilai $-t_{\text {tabel }} \leq \pm$ thitung $\leq t_{\text {tabel }}$ Ha diterima jika $-t_{\text {tabel }} \geq$ \pm thitung $\geq t_{\text {tabel }}$. Sedangkan pada analisis uji N-gain digunakan untuk mengetahui ada tidaknya peningkatan kemampuan berfikir kreatif mahasiswa setelah penggunaan software modellus sebagai media simulasi virtual. Untuk mencari nilai indeks $\mathrm{N}$-gain menggunakan Persamaan 1.

$$
N-\text { Gain }=\frac{\bar{X} \text { Post Test }-\bar{X} \text { Pre Test }}{\text { Skor Maksimum }-\bar{X} \text { Pre Test }}
$$

Sumber (Meltzer, 2002)

Keterangan:

$\bar{X}$ Post test $=$ Nilai rata - rata post test

$\bar{X}$ Pre test $=$ Nilai rata-rata pretes

Nilai N-gain dapat direpresentasikan dalam 5 kreteria (Meltzer, 2002). adapun kreteria tersebut dapat ditampilkan pada tabel 5 berikut:

Tabel 5. Klasifikasi kriteria N-gain

\begin{tabular}{cc}
\hline Perolehan N-Gain & Kreteria kenaikan \\
\hline $\mathrm{g} \leq 0,20$ & Kenaikan sangat rendah \\
$0,21-0,40$ & Kenaikan rendah \\
$0,41-0,60$ & Kenaikan sedang \\
$0,61-0,80$ & Kenaikan tinggi \\
$0,81-1,00$ & Kenaikan sangat tinggi \\
\hline
\end{tabular}

\section{HASIL DAN PEMBAHASAN}

Penelitian ini bertujuan untuk mengetahui pengaruh penggunaan software modellus sebagai media simulasi virtual terhadap kemampuan berpikir kreatif mahasiswa pada materi Gelombang. Penelitian diterapkan pada mahasiswa prodi rekayasa sistem komputer semester II Universitas Bina Insan Lubuklinggau pada tahun ajaran 2020/2021. Sebagai kelas eksperimen digunakan kelas reguler A4 dan kelas kontrol digunakan kelas reguler A1. Pengambilan data penelitian pada kelas kontrol dan eksperimen yaitu sebelum atau data pretest dan sesudah atau data posttest. Pada kelas ekperimen setelah pengambilan data pretes 
dilakukan treatment atau pemberian pembelajaran menggunakan software modellus sebagai media simulasi virtual terhadap kemampuan berpikir kreatif mahasiswa, sedangkan pada kelas kontrol tidak diberikan. Hasil tes pretest dan posttest pada kelas kontrol dan eksperimen kemampuan berpikir kreatif dapat dilihat pada tabel 6 .

Tabel 6. Hasil tes pretest dan posttest pada kelas kontrol dan eksperimen

\begin{tabular}{llllll}
\hline \multicolumn{1}{c}{ Kelas Eksperimen } & & \multicolumn{2}{c}{ Kelas Kontrol } \\
\hline Data statistik & $\begin{array}{c}\text { Data } \\
\text { Pretest }\end{array}$ & $\begin{array}{c}\text { Data } \\
\text { Posttest }\end{array}$ & $\begin{array}{c}\text { Data } \\
\text { statistik }\end{array}$ & $\begin{array}{c}\text { Data } \\
\text { Pretest }\end{array}$ & $\begin{array}{c}\text { Data } \\
\text { Postest }\end{array}$ \\
\hline Xmax & 70 & 95 & Xmax & 65 & 85 \\
Xmin & 30 & 55 & Xmin & 30 & 45 \\
Rata-rata & 50,30 & 78,50 & Rata-rata & 45,50 & 66,50 \\
SD & 9,07 & 10,97 & SD & 9,28 & 8,54 \\
Kategori & 5 siswa & 13 siswa & Kategori & 5 siswa & 8 \\
kemampuan & & & Tinggi & & \\
$\begin{array}{l}\text { Tinggi } \\
\text { Kategori }\end{array}$ & 15 siswa & 10 siswa & Kategori & 17 siswa & 15 siswa \\
kemampuan & & & Sedang & & \\
$\begin{array}{l}\text { Sedang } \\
\text { Kategori }\end{array}$ & 5 siswa & 2 siswa & Kategori & 3 siswa & 2 siswa \\
kemampuan & & & Rendah & & \\
Rendah & & & & & \\
\hline
\end{tabular}

Dari tabel 6 diatas dapat diketahui bahwa nilai tes rata-rata dari seluruh aspek (fluency, fleksibel, orisinal dan elaboration ) pada hasil pretes pada kelas eksperimen adalah 50,30 dan posttest 78,50 atau terdapat peningkatan rata-rata hasil tes mahasiswa sebesar 28,2 atau $56 \%$ dari rata-rata skor awal. Sedangkan nilai tes rata-rata dari seluruh aspek (fluency, fleksibel, orisinal dan elaboration ) pada pretes kelas kontrol dengan nilai 45,50 dan posttes 66,50 atau terdapat peningkatan rata-rata hasil tes mahasiswa sebesar 21 atau $46 \%$ dari ratarata skor awal.dari skor maksimum. Adapun hasil pada kelasifikasi pembagian kemampuan mahasiswa baik pada kelas eksperimen dan kontrol sama-sama mengalami peningkatan terutama pada katagori kemampuan tinggi, dimana kenaikan jumalah mhasiswa tersebut didominasi pada kelas eksperimen yaitu sebanyak 8 mahasiswa dan 3 mahasiswa pada kelas kontrol. Sedangkan jiika dilihat pada tiap aspek indikator kemampuan berfikir kreatif mahaiswa yaitu pada aspek kelancaran atau fluency, kemampuan berpikir fleksibel, orisinal, dan kemampuan memperinci atau elaboration dapat dilihat pada gambar 4 berikut. 


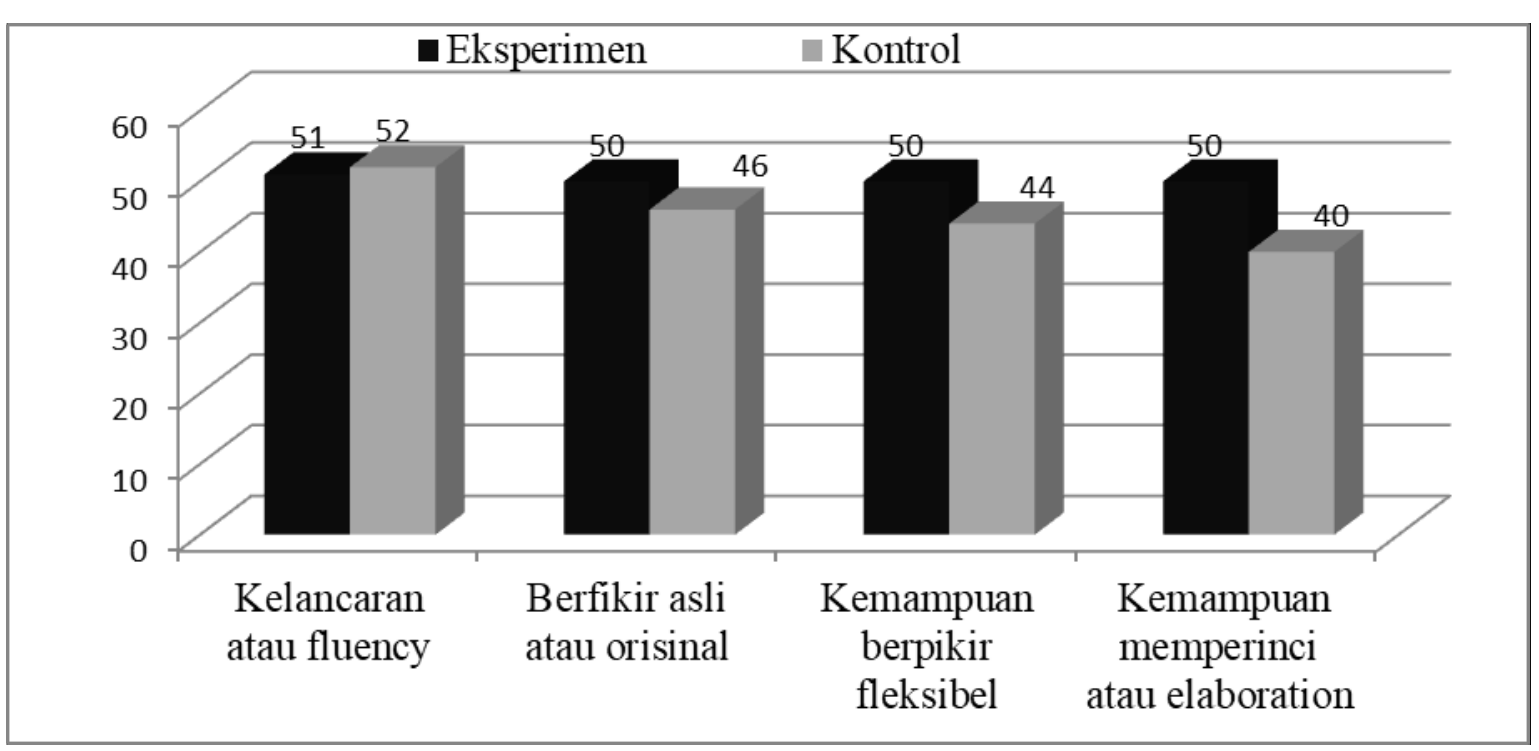

Gambar 4. Rata-rata data hasil pretest kemampuan berfikir kreatif mahasiswa pada setiap aspek Indikator untuk kelas eksperimen dan kelas kontrol

Berdasarkan gambar 4 dapat diketahui bahwa kemampuan berfikir kratif mahasiswa untuk rata-rata setiap aspek indikator pada kelas eksperimen yaitu aspek kelancaran atau fluency didapatkan nilai 51 sedangkan pada orisinal, fleksibel dan elaborasi 50 hal ini menunjukan bahawa kemampuan berfikir kreatif mahasiswa pada setiap aspek Indikator masih sangat rendah. Sedangkan kemampuan berfikir kratif mahasiswa untuk rata-rata setiap aspek indikator pada kelas kontrol yaitu untuk aspek kelancaran atau fluency didapatkan nilai 52 , orisinal 46, fleksibel 44 dan elaborasi 50 juga masih rendah. Hal ini dikarenakan mahasiswa belum memiliki sifat berpikir kreatif seperti lancar atau fluency, berfikir asli atau orisinal, kemampuan memperinci atau elaboration. Dari hasil pretest tersebut, maka perlu dilakukan upaya peningkatan kemampuan berfikir kreatif dengan cara pemberian treatment ataupun metode pembelajaran yang tepat. Treatmen tersebut berupa penggunaan software modellus sebagai media simulasi virtual. Adapun hasil posttes setelah pemberian treadment kemampuan berfikir kratif mahasiswa ditunjukkan pada gambar 5 berikut. 


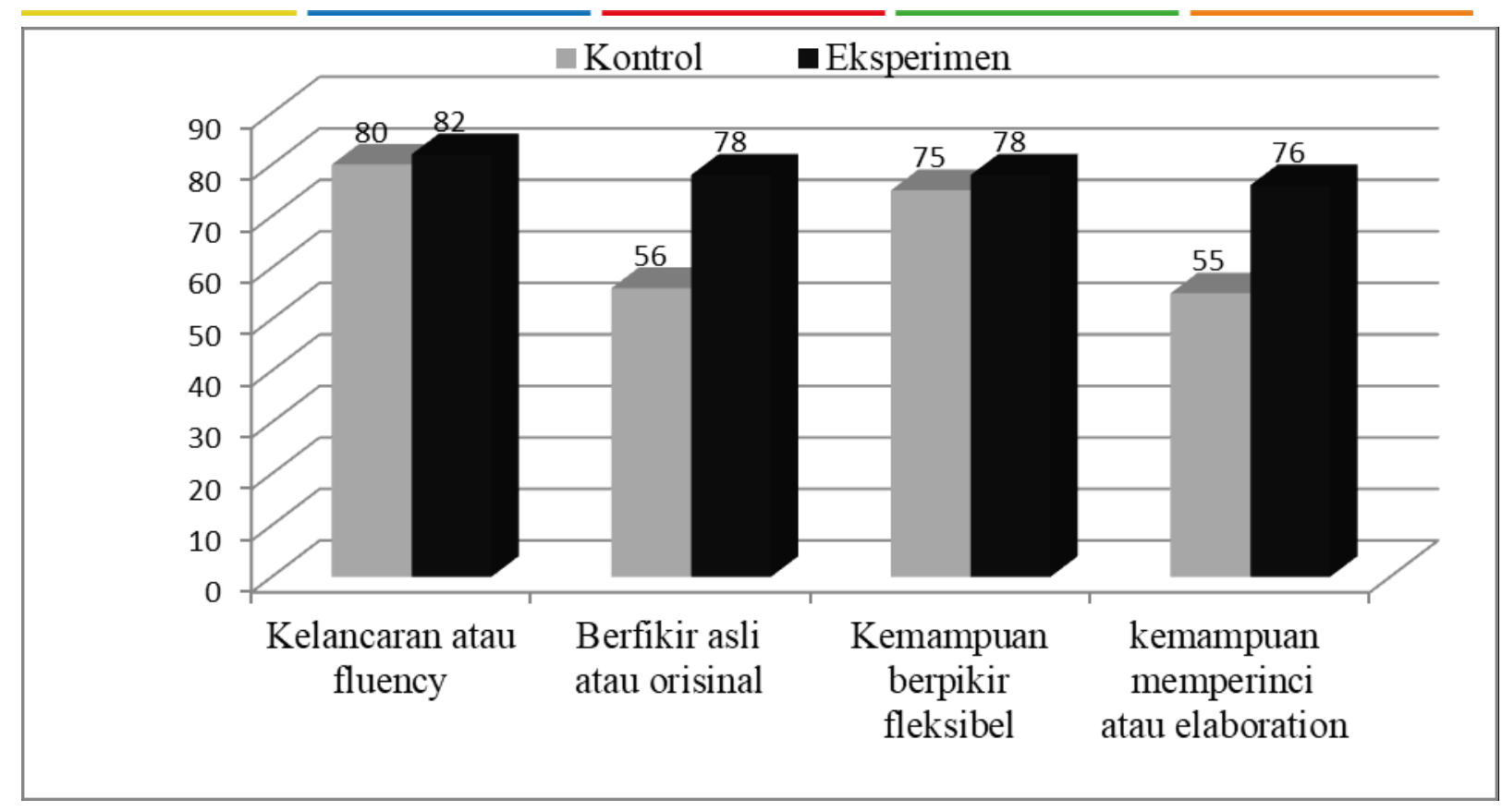

Gambar 5. Rata-rata data hasil posttest kemampuan berfikir kreatif mahasiswa pada setiap aspek Indikator untuk kelas eksperimen dan kelas kontrol

Berdasarkan gambar 5 setelah pemberian treadment dapat diketahui bahwa kemampuan berfikir kratif mahasiswa untuk rata-rata setiap aspek indikator pada kelas eksperimen yaitu aspek kelancaran mendapatkan nilai 82 , elaborasi 76 , sedangkan pada orisinal dan fleksibel 78 menunjukan bahawa kemampuan berfikir kreatif mahasiswa pada setiap aspek Indikator mengalami peningkatan cukup signifikan. Sedangkan pada kelas kontrol juga mengalami kenaikan kemampuan berfikir kreatif yaitu pada kelancaran atau fluency didapatkan nilai 80 dan fleksibel 78, akan tetapi ada beberapa aspek yang masih cukup rendah yaitu pada aspek orisinal dan elaboration. Kemampuan berfikir kreatif baik kelas eksperimen maupun kelas control secara umum sama-sama mengalami peningkatan pada hasil posttes, akan tetapi besar peningkatan tersebut perlu dilakukan uji setatistik lebih mendalam untuk mengetahui perbedaan hasil dari setiap treatment. Uji statistk tersebut dapat berupa uji N-gain. Adapun hasil perhitungan uji $\mathrm{N}$-gain pada kelas kontrol yaitu $N$-gain $=\frac{66,50-45,50}{85-45,50}=0,53$ artinya kenaikan kemampuan berfikir kreatif pada kelas kontrol jika hasil uji $\mathrm{N}$-gain diinterprestasikan pada tabel 5 yaitu pada katagori sedang. Sedangkan hasil perhitungan uji $\mathrm{N}$-gain pada kelas eksperimen yaitu $N-$ gain $=\frac{78,50-50,30}{95-50,30}=0,63$ hasil uji $\mathrm{N}$-gain ini jika diinterprestasikan pada tabel 5 yaitu berada pada katagori tinggi artinya penggunaan Puplished at https://ojs.stkippgri-lubuklinggau.ac.id/index.php/SJPIF 
software modellus sebagai media simulasi virtual pada pengajaran fisika sangat mempengaruhi kenaikan kemampuan berfikir kreatif mahasiswa. Pengujian selanjutnya yaitu dilakukan uji hipotesis untuk mengetahui perbedaan pengaruh diterapkannya penggunaan software modellus sebagai media simulasi virtual terhadap kemampuan berpikir kreatif mahasiswa. Adapun hasil dari uji hipotesis menggunakan uji t yang dilakukan dengan menggunakan software SPSS dapat dilihat pada Tabel 7.

Tabel 7. Hasil uji-t

\begin{tabular}{cccc}
\hline $\begin{array}{c}\text { Number } \\
\text { Probability }\end{array}$ & $\begin{array}{c}\text { Number } \\
\text { Deg_freedo } \\
\mathrm{m}\end{array}$ & ttabel & thitung \\
\hline $5 \%$ & 48 & 2,021 & 5,733 \\
\hline
\end{tabular}

Pada tabel 7 dapat diketahui bahwa nilai $-t_{\text {tabel }}> \pm t_{\text {hitung }}>t_{\text {tabel }}$, maka hipotesis alternatif (Ha) dalam penelitian ini diterima sehingga memiliki arti yaitu $\mathrm{Ha}$ : Terdapat pengaruh penggunaan software modellus sebagai media simulasi virtual terhadap kemampuan berpikir kreatif mahasiswa pada mata kuliah fisika. Gambaran lebih jelas dari interprestasi penerimaan dan penolakan Ho dapat dilihat pada gambar grafik 6.

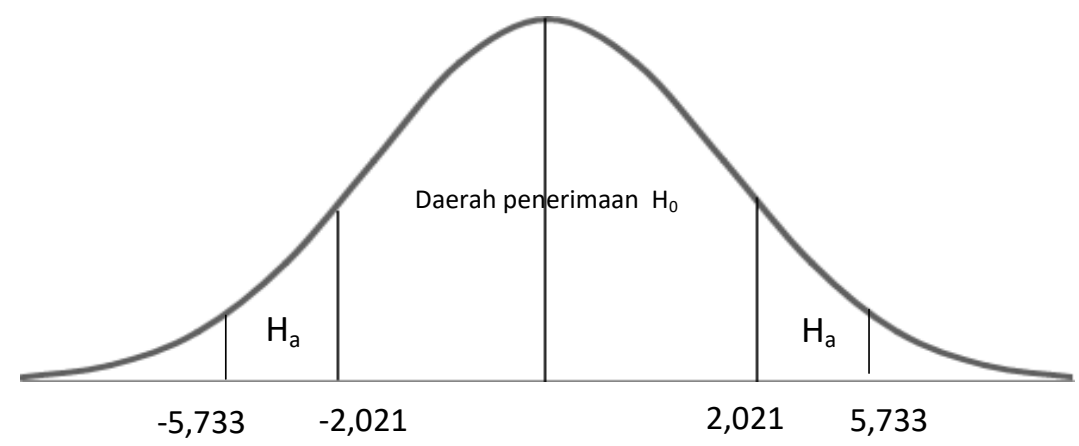

Gambar 6. Grafik penerimaan dan penolakan $\mathrm{H}_{\mathrm{o}}$ pada uji-t dua pihak

\section{SIMPULAN DAN SARAN}

Kesimpulan dari penelitian yang telah dilakukan tentang penggunaan software modellus sebagai media simulasi virtual terhadap kemampuan berpikir kreatif mahasiswa pada mata kuliah fisika yaitu dapat meningkatkan kemampuan berfikir kreatif mahasiswa. Peningkatan kemampuan berfikir kreatif mahasiswa dapat dilihat dari membaiknya perolehan hasil belajar yang signifikan. Kenaikan hasil belajar setelah penggunaan software modellus 
sebagai media simulasi virtual untuk pengajaran fisika memperoleh nilai uji $\mathrm{N}$-gain sebesar 0,63, artinya jika diinterprestasikan pada tabel 5 yaitu berada pada katagori tinggi.

\section{DAFTAR PUSTAKA}

Angellena, M., Switoro, E., \& Putri, D. H. (2020). Pengaruh Pembelajaran Dengan Model Problem Solving Fisika (Psf) Terhadap Prestasi Belajar Dan Kemampuan Berpikir Kritis. Jurnal Kumparan Fisika, 3(2), 83-90. https://doi.org/10.33369/jkf.3.2.83-90

Anisa, M. K., Permana P, N. D., \& Nova, T. L. (2020). Penggunaan Simulasi Virtual Pada Pembelajaran Fisika Untuk Meningkatkan Higher Order Thinking Skill (Hots) Siswa : Meta Analisis. Jurnal Kumparan Fisika, 3(2), 163-170. https://doi.org/10.33369/jkf.3.2.163-170

Arikunto, S. (2016). Dasar-Dasar Evaluasi Pendidikan (R. Damayanti (ed.); Edisi kedu). Bumi Aksara.

Creswell, J. W. (2011). Educational Research Planning, Conducting, and Evaluating Quantitative and Qualitative Research (M. Buchholtz (ed.)). Pearson Education.

Fahrudin, A. (2018). Universitas Papua Application and Its Effect on Elasticity Learning Achievement. 1(1), 22-33.

Gong, Y. (2021). Application of virtual reality teaching method and artificial intelligence technology in digital media art creation. Ecological Informatics, 63(January), 101304. https://doi.org/10.1016/j.ecoinf.2021.101304

Leen, C. C., Hong, H., Kwan, F. N. H., \& Ying, T. W. (2014). Creative and Critical Thinking in Singapore Schools. In An Institure of Nanyang Technological University (Vol. 2, Issue 2).

Lusiyana, A., Rohim, S., \& Rohman, F. (2017). Pengaruh Pendekatan Open-Ended untuk Meningkatkan Kemampuan Berpikir Kreatif Siswa pada Mata Pelajaran Fisika Berbasis Perangkat Lunak Modellus. JIPFRI (Jurnal Inovasi Pendidikan Fisika Dan Riset Ilmiah), 1(2), 65-74. https://doi.org/10.30599/jipfri.v1i2.116

Malina, I., Yuliani, H., \& Syar, N. I. (2021). Analisis Kebutuhan E-Modul Fisika sebagai Bahan Ajar Berbasis PBL di MA Muslimat NU. Sılamparı Jurnal Pendıdıkan Ilmu Fisıka, 3(1), 70-80.

Melianti, E., Risdianto, E., \& Swistoro, E. (2020). Pengembangan Media Pembelajaran Berbasis Multimedia Interaktif Menggunakan Macromedia Director Pada Materi Usaha Dan Energi Kelas X. Jurnal Kumparan Fisika, 3(1), 1-10. https://doi.org/10.33369/jkf.3.1.1-10

Meltzer, D. E. (2002). The relationship between mathematics preparation and conceptual learning gains in physics: A possible "hidden variable" in diagnostic pretest scores. American Journal of Physics, 70(12), 1259-1268. https://doi.org/10.1119/1.1514215 
Neves, R. G. M., Neves, M. C., \& Teodoro, V. D. (2013). Modellus: Interactive computational modelling to improve teaching of physics in the geosciences. Computers and Geosciences, 56, 119-126. https://doi.org/10.1016/j.cageo.2013.03.010

Neves, R. G., Silva, J. C., \& Teodoro, V. D. (2010). Computational Modelling with Modellus: An Enhancement Vector for the General University Physics Course. 1-12. http://arxiv.org/abs/1006.4662

Nurdiana, H., Sajidan, \& Maridi. (2020). Creative thinking skills profile of junior high school students in science learning. Journal of Physics: Conference Series, 1567(2), 316-328. https://doi.org/10.1088/1742-6596/1567/2/022049

Radianti, J., Majchrzak, T. A., Fromm, J., \& Wohlgenannt, I. (2020). A systematic review of immersive virtual reality applications for higher education: Design elements, lessons learned, and research agenda. Computers and Education, 147, 103778. https://doi.org/10.1016/j.compedu.2019.103778

Rezeki, S., \& Ishafit, I. (2017). Pengembangan lembar kerja siswa ( LKS ) berbantuan media simulasi dengan modellus untuk pembelajaran kinematika di sekolah menengah atas. Etnosains Dan Peranannya Dalam Menguatkan Karakter Bangsa, 130-133.

Sari, R. P., Sakti, I., \& Hamdani, D. (2021). Pengembangan Lembar Kerja Peserta Didik (Lkpd) Fluida Statis Dengan Scientific Approach Untuk Meningkatkan Keterampilan Berpikir Kritis Siswa Sman Kota Bengkulu. DIKSAINS: Jurnal Ilmiah Pendidikan Sains, 1(1), 1-9. https://doi.org/10.33369/diksains.v1i1.14692 